\title{
Responses to postruminal infusions of glucose and casein in lactating goats
}

\author{
By S. S. E. RANAWANA* AND R. C. KELLAWAY \\ Department of Animal Husbandry, University of Sydney, \\ Camden, New South Wales 2570, Australia \\ (Received I 5 fune 1976-Accepted 27 August 1976)
}

\begin{abstract}
1. A study was made in goats of the response in terms of milk production, nitrogen utilization, plasma amino acids and glucose kinetics to postruminal infusions of glucose and casein. Goats in mid-lactation, housed in metabolism cages, were fed on $2 \mathrm{~kg}$ basal ration (containing $112 \mathrm{~g}$ crude protein $(\mathrm{N} \times 6.25) / \mathrm{kg}$ ) $/ \mathrm{d}$ alone (control) and with daily infusions into the abomasum of $45 \mathrm{~g}$ casein or $45 \mathrm{~g}$ glucose.

2. Milk production increased with casein infusion $(P<0.01)$, but not with glucose infusion, being $\mathrm{I} \cdot 59, \mathrm{I} \cdot 86$ and $\mathrm{I} \cdot 62 \mathrm{~kg} / \mathrm{d}$ with the control, casein and glucose infusions respectively. Milk composition was unaffected except for milk fat, which was decreased by the glucose infusion.

3. The goats were in positive $\mathrm{N}$ balance on the basal ration. Milk $\mathrm{N}$ output increased with casein infusion, by an amount equivalent to $27 \%$ of the infused $\mathrm{N}$.

4. The concentration of dispensable amino acids in arterial plasma was decreased with casein infusion and increased with glucose infusion.

5. Glucose kinetic measurements with control, casein and glucose infusions indicated that pool sizes were 247,279 and $302 \mathrm{mg} / \mathrm{kg}$ live weight ${ }^{0.75}$, and irreversible losses were $5.5,6.7$ and $7.0 \mathrm{mg} / \mathrm{kg}$ live weight $\mathrm{t}^{0.75}$ per min respectively. The differences between the results obtained from the glucose and casein infusions were not significant $(P<0.05)$.

6 . The results of the experiment indicate that the increased milk production obtained when casein was infused was not due to enhanced gluconeogenesis.
\end{abstract}

In a previous report (Ranawana \& Kellaway, 1977), we indicated that administration of casein postruminally in goats increased milk production by up to $22 \%$. Positive but smaller responses have been reported in cows and Clark (1975), who reviewed these results, suggested that one way in which casein may have evoked the response was by supplying glucogenic amino acids with a resulting increase in the availability of glucose to the mammary gland.

Hardwick, Linzell \& Price (I96I) found that glucose is essential for milk secretion and Annison \& Linzell (1964) found that $60-85 \%$ of the available glucose is utilized by the mammary gland in the lactating goat. The supply of glucose in the ruminant is largely dependent on gluconeogenesis since normally little glucose is absorbed from the intestine. Although propionate is known to be the chief precursor of glucose, amino acids are also a major source (Wolff \& Bergman, I972). Therefore, the response to casein may have been due to an increased availability of glucogenic amino acids. Vik-Mo, Emery \& Huber (1974) reported that glucose infused into the abomasum of cows was as effective as casein in stimulating milk production in one in four experiments. In other experiments with cows, casein, but not glucose, stimulated milk production when infused abomasally (Clark, Spires \& Derrig, r973).

In the present study, casein and glucose were infused abomasally into lactating

* Present address: Veterinary Research Institute, Peradeniya, Sri Lanka. 
Table I. Composition of basal ration fed to goats $(\mathrm{g} / \mathrm{kg})$

Ingredient

Milled barley

Lucerne chaff

Oat straw

Molasses*

Bone meal

620
200
100
70
10

Analysis

$\begin{array}{lc}\text { Dry matter } & 879 \\ \text { Crude protein } & 112 \\ \text { (nitrogen } \times 6 \cdot 25) & \\ N & 17 \cdot 9 \\ \text { Acid-detergent fibre } & 179 \\ \text { Acid-insoluble lignin } & 48\end{array}$

* Molatein: Souter Rural Industries Pty Ltd, Sydney, Australia. Composition (g/kg): crude protein 90 , crude fat $10-25$, crude fibre $28-40$, ash $86, \mathrm{~N}$-free extract 720 .

goats. Measurements were made of the relative effects of these treatments on the production of milk and milk constituents, nitrogen balance, free amino acids in arterial plasma and glucose kinetics. A preliminary report of the results of this experiment has already been made (Ranawana \& Kellaway, 1976).

\section{EXPERIMENTAL}

\section{Design}

The experiment was conducted in a $3 \times 3$ Latin Square design, with three animals and three treatments, and was carried out in three periods so that each animal was subjected to each treatment. Each period lasted $\mathrm{I}_{4} \mathrm{~d}$ and all measurements were made during the last $7 \mathrm{~d}$ of each period.

\section{Animals}

Three multiparous Saanen goats of about $35 \mathrm{~kg}$ live weight in mid-lactation and with similar milk yields were used. The surgical preparation and management of the animals was similar to that described previously (Ranawana \& Kellaway, 1977).

\section{Feeding}

The ration, the composition of which is given in Table $\mathbf{I}$, was mixed, pelleted and $2 \mathrm{~kg}$ was fed to each goat daily. The animals were deliberately restricted to $2 \mathrm{~kg}$ (approximately $80 \%$ of the ad lib. intake) so that treatment effects would not be confounded by varying $\mathrm{N}$ intakes.

\section{Infusions}

The casein infusate and infusion procedures were identical to those used previously (Ranawana \& Kellaway, 1977) and the glucose was dissolved in distilled water. The casein and glucose solutions were infused at the rate of $900 \mathrm{ml} / \mathrm{d}$.

\section{Milking}

Goats were milked by hand twice/d, by the same milker, throughout the experiment. Milk was weighed, sampled $\left(5^{\circ} \mathrm{g} / \mathrm{kg}\right)$ and stored at $4^{\circ}$ after adding one drop formalin $/ 20 \mathrm{ml}$ milk. Later, milk samples were homogenized and analysed as described previously (Ranawana \& Kellaway, I977). 


\section{$N$ balance}

Urine and faeces were collected and measured daily from each animal during the experimental periods. Storage and analytical procedures were as described previously (Ranawana \& Kellaway, 1977).

\section{Blood samples and glucose kinetics}

On the last day of each period, a $30 \mathrm{ml}$ blood sample was taken from the exteriorized carotid artery in each animal. Local analgesics were used to avoid any stress reaction. Blood was deproteinized (Perry \& Hansen, 1959) after the addition of internal standards for amino acid analysis, and stored at $-10^{\circ}$. Later, the plasma was analysed for glucose (Huggett \& Nixon, 1957) and for individual amino acids by ion-exchange chromatography using an amino acid AutoAnalyzer (TSM; Technicon Instrument Corporation, Tarry Town, New York, USA).

For measurements of glucose kinetics, both jugular veins were catheterized and the catheters filled with heparinized saline ( $9 \mathrm{~g}$ sodium chloride/l) (I $\mathrm{mg}$ heparin $/ \mathrm{ml}$ saline) on the day before the experiment. The next morning, $200 \mu \mathrm{Ci}$ [U_- $\left.{ }^{14} \mathrm{C}\right]$ glucose (Radiochemical Centre, Amersham, Bucks., UK) were injected into one vein at o mins, and $4 \mathrm{ml}$ samples of blood were withdrawn through the opposite cannula as close as possible to the following intervals (min): $5,10,15,20,25,30,40,50,60,80,100,120$, $150,180,240$ and 300 ; exact intervals were noted. Blood samples were transferred to test-tubes containing $0.5 \mathrm{mg}$ heparin, centrifuged and the plasma stored at $-10^{\circ}$. Later, the specific radioactivity (SRA) of blood glucose was determined by the method of Schmidt, Smith \& Young (1975) in which deproteinized plasma is passed through a column of anion-exchange resin in order to remove organic ions before determining radioactivity. Portions of eluate were analysed for glucose as described previously and $\mathrm{I} \mathrm{ml}$ portions were used to determine radioactivity after adding $15 \mathrm{ml}$ fluor $(625 \mathrm{ml}$ toluene, $357 \mathrm{ml}$ Triton X-100 (Ajax Chemicals Ltd, Syndey, Australia), $4 \mathrm{~g}$ PPO), using a Packard Tri-carb liquid scintillating spectrophotometer (Packard Instrument Co., Downers Grove, Illinois, USA).

The SRA of blood glucose $v$. time was plotted and the pool size and irreversible loss of glucose-C were calculated graphically according to the procedure of Katz, Dunn, Chenoweth \& Golden (1974).

\section{RESULTS}

One goat refused $60 \mathrm{~g}$ basal ration/d when infused with casein and $33^{\circ} \mathrm{g}$ basal ration/d when infused with glucose. The animal appeared to be in good health and so these values were included in the results.

\section{Milk production}

Values in Table 2 indicated that milk production was significantly $(P<0.01)$ increased by the casein infusion but not by the glucose. The production of milk constituents other than milk fat, closely paralleled milk production. Fat content of milk was significantly $(P<0.05)$ reduced by the glucose infusion. 
Table 2. Production of milk and milk constituents by goats given the basal ration* alone (control) and with daily abomasal infusions of $45 \mathrm{~g}$ casein or $45 \mathrm{~g}$ glucose

(Mean values for three measurements/treatment)

\begin{tabular}{|c|c|c|c|c|}
\hline \multirow[b]{2}{*}{ Constituent } & \multicolumn{3}{|c|}{ Treatment } & \multirow{2}{*}{$\begin{array}{c}\text { SE of } \\
\text { treatmen } \\
\text { means }\end{array}$} \\
\hline & Control & Casein & Glucose & \\
\hline Milk (g/d) & $15^{8} 7^{a}$ & $1862^{b}$ & $162 \mathrm{I}^{a}$ & $3^{\circ} \cdot 9$ \\
\hline $\begin{array}{l}\text { Total solids: } \\
\text { g/d } \\
\text { g/l }\end{array}$ & $\begin{array}{l}213 \cdot 1^{a} \\
\mathrm{r}_{34} \cdot 7\end{array}$ & $\begin{array}{l}250 \cdot 7^{b} \\
135.3\end{array}$ & $\begin{array}{l}202 \cdot 7^{a} \\
125 \cdot 2\end{array}$ & $\begin{array}{l}4 \cdot 8 \\
3 \cdot 4\end{array}$ \\
\hline $\begin{array}{l}\text { Fat: } \\
\quad \mathrm{g} / \mathrm{d} \\
\mathrm{g} / \mathrm{l}\end{array}$ & $\begin{array}{l}73 \cdot 7^{a b} \\
46 \cdot 1^{a}\end{array}$ & $\begin{array}{l}80 \cdot 5^{\alpha} \\
43 \cdot 5^{a b}\end{array}$ & $\begin{array}{l}62 \cdot 1^{b} \\
38 \cdot 3^{b}\end{array}$ & $\begin{array}{l}3.6 \\
2 \cdot 0\end{array}$ \\
\hline $\begin{array}{l}\text { Solids-not-fat: } \\
\text { g/d } \\
\text { g/1 }\end{array}$ & $\begin{array}{l}139 \cdot 4^{a} \\
88 \cdot 2\end{array}$ & $\begin{array}{c}170 \cdot 3^{b} \\
9 \mathrm{I} \cdot 8\end{array}$ & $\begin{array}{c}140 \cdot 7^{a} \\
86 \cdot 9\end{array}$ & $\begin{array}{l}2.4 \\
1.6\end{array}$ \\
\hline $\begin{array}{l}\text { Total protein: } \\
\text { g/d } \\
\text { g/l }\end{array}$ & $\begin{array}{l}53 \cdot 8^{a} \\
33 \cdot 9\end{array}$ & $\begin{array}{l}64 \cdot 4^{b} \\
34 \cdot 6\end{array}$ & $\begin{array}{l}50 \cdot 9^{a} \\
31 \cdot 4\end{array}$ & $\begin{array}{l}I \cdot 2 \\
I \cdot 0\end{array}$ \\
\hline $\begin{array}{l}\text { Casein: } \\
\text { g/d } \\
\mathrm{g} / \mathrm{l}\end{array}$ & $\begin{array}{l}43 \cdot 2^{a} \\
27 \cdot 4\end{array}$ & $\begin{array}{l}52 \cdot 4^{b} \\
28 \cdot 3\end{array}$ & $\begin{array}{l}40 \cdot 5^{a} \\
25 \cdot 0\end{array}$ & $\begin{array}{l}1 \cdot 7 \\
1 \cdot 2\end{array}$ \\
\hline Casein: total protein & $0.8 \mathbf{I}$ & 0.82 & 0.80 & 0.01 \\
\hline $\begin{array}{l}\text { Lactose: } \\
\mathrm{g} / \mathrm{d} \\
\mathrm{g} / \mathrm{l}\end{array}$ & $\begin{array}{l}76 \cdot 7^{a} \\
48 \cdot 5\end{array}$ & $\begin{array}{l}9 \mathrm{I} \cdot \mathrm{O}^{b} \\
49^{\circ} \mathrm{O}\end{array}$ & $\begin{array}{l}78 \cdot 5^{a} \\
48 \cdot 5\end{array}$ & $\begin{array}{l}2 \cdot 4 \\
0.4\end{array}$ \\
\hline
\end{tabular}

Table 3. Dry matter (DM) and ntirogen balance results for goats given the basal ration* alone (control) and with daily abomasal infusions of $45 \mathrm{~g}$ casein or $45 \mathrm{~g}$ glucose

(Mean values for three measurements/treatment)

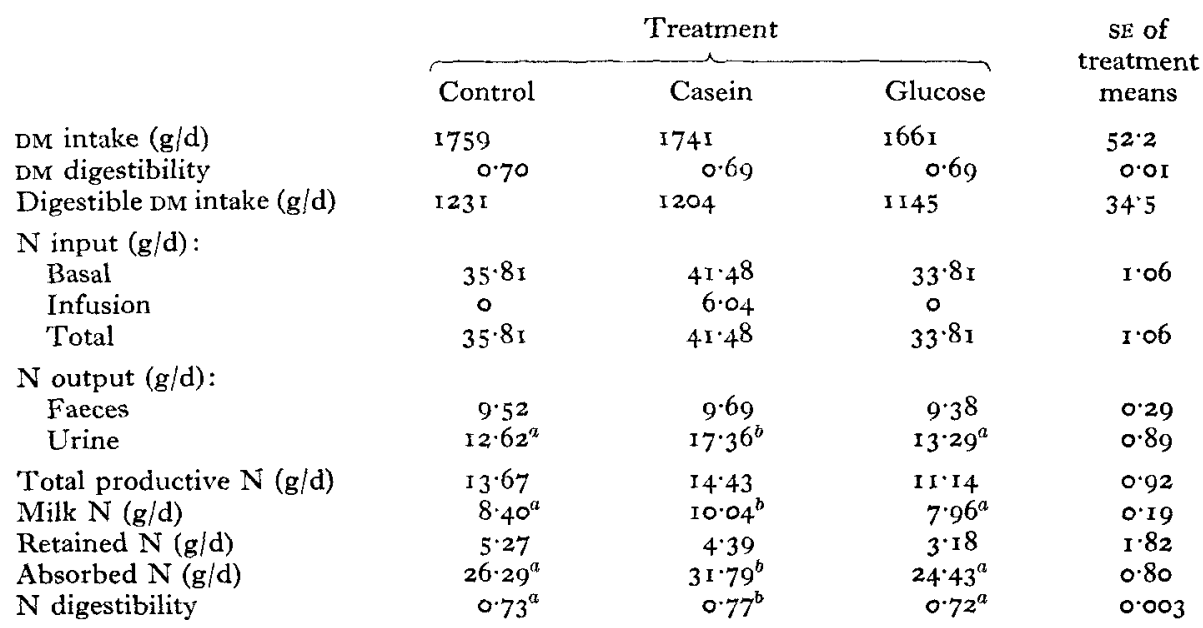

$a, b$ Values with unlike superscripts differ significantly $(P<0.05)$.

* For details of composition, see Table $x$. 
Table 4. Carotid artery levels of plasma free amino acids ( $\mu$ mol/l plasma) for goats given the basal ration* alone (control) and with daily abomasal infusions of $45 \mathrm{~g}$ casein or $45 \mathrm{~g}$ glucose

(Mean values for three measurements/treatment)

\begin{tabular}{|c|c|c|c|c|}
\hline & & Treatmer & & SE of \\
\hline & Control & Casein & Glucose & means \\
\hline Indispensable amin & & & & \\
\hline Threonine & 60 & 64 & 71 & $I I \cdot 6$ \\
\hline Valine & Iro & 171 & 126 & $3+3$ \\
\hline Methionine & 12 & I3 & I7 & 3.0 \\
\hline Isoleucine & 99 & I4I & 96 & $23 \cdot 3$ \\
\hline Leucine & 77 & 122 & 84 & $22 \cdot 0$ \\
\hline Phenylalanine & 40 & $3^{8}$ & 45 & $3 \cdot 9$ \\
\hline Lysine & 97 & 163 & 149 & 43.9 \\
\hline Histidine & IOI & 175 & 123 & $25 \cdot 2$ \\
\hline Arginine & 89 & $12 I$ & 135 & $24 \cdot 2$ \\
\hline Total & 684 & 1007 & 837 & $179 \cdot 7$ \\
\hline Dispensable amino & & & & \\
\hline Aspartic acid & $3 I$ & $3 \mathrm{I}$ & 40 & 5.7 \\
\hline Serine & $108^{a}$ & $104^{a}$ & $165^{b}$ & $12 \cdot 8$ \\
\hline $\begin{array}{l}\text { Glutamic acid }+ \\
\text { glutamine }\end{array}$ & 376 & 306 & 355 & $34 \cdot 7$ \\
\hline Proline & 84 & 162 & 123 & $25 \cdot 7$ \\
\hline Glycine & $775^{a b}$ & $645^{a}$ & $899^{b}$ & 60.5 \\
\hline Alanine & 325 & 298 & 383 & $36 \cdot 8$ \\
\hline Cystine & 14 & 20 & 18 & $3 \cdot 4$ \\
\hline Tyrosine & 48 & 57 & 61 & 7.8 \\
\hline Ornithine & 41 & 61 & $5^{8}$ & II'3 \\
\hline Total & $1804^{b}$ & $1684^{a}$ & $2103^{\circ}$ & $23 \cdot 2$ \\
\hline Total amino acids & 2488 & 2691 & 2940 & I $94 \cdot 8$ \\
\hline $\begin{array}{l}\text { Ratio, } \\
\text { indispensable : disp }\end{array}$ & ible & 0.60 & 0.40 & 0.091 \\
\hline
\end{tabular}

\section{$N$ balance}

$\mathrm{N}$ balance results are given in Table 3 . The basal dry matter and $\mathrm{N}$ intakes were similar.

The infused $\mathrm{N}$ in casein was apparently all absorbed since no increase in faecal $\mathrm{N}$ was found. The $\mathrm{N}$ digested and absorbed was significantly increased $(P<0.05)$ during the casein infusion. Although milk $\mathrm{N}$ was significantly increased $(P<0.05)$ when casein was infused, $73 \%$ of the infused $N$ appeared in urine $(P<0.05)$.

The goats were in positive $\mathrm{N}$ balance when given the basal ration and the quantity of $\mathrm{N}$ retained was not significantly $(P<0.05)$ affected by treatment.

\section{Plasma amino acids}

Concentrations of amino acids in arterial plasma are given in Table 4. Total dispensable amino acid level was significantly $(P<0.05)$ reduced by the casein infusion and increased significantly $(P<0.05)$ by glucose infusion. Levels of circulating serine were significantly increased $(P<0.05)$ during glucose infusion. 
Table 5. Glucose kinetics results for goats given the basal ration* alone (control) and with daily abomasal infusions of $45 \mathrm{~g}$ casein or $45 \mathrm{~g}$ glucose

(Mean values for three measurements/treatment)

Pool size:

g

$\mathrm{mg} / \mathrm{kg}$ live weight

$\mathrm{mg} / \mathrm{kg}$ live weight $\mathbf{0 . 7 5}$

Irreversible loss $(/ \mathrm{d})$ :

g

$\mathrm{g} / \mathrm{kg}$ live weight

$\mathrm{g} / \mathrm{kg}$ live weight $\mathbf{0 . 7 5}$

Irreversible loss $(/ \mathrm{min})$ :

$\mathrm{mg}$

$\mathrm{mg} / \mathrm{kg}$ live weight

$\mathrm{mg} / \mathrm{kg}$ live weight $\mathrm{t}^{0.75}$

Ratio, lactose production : irreversible glucose loss

Plasma glucose concentration (mmol/l)

$\begin{array}{rrrr}\text { Control } & \text { Casein } & \text { Glucose } & \begin{array}{r}\text { SE of } \\ \text { treatment } \\ \text { means }\end{array} \\ 5.15 & 5.82 & 6.27 & 0.29 \\ 89.90 & 101.50 & 110.60 & 5.60 \\ 247.10 & 278.80 & 302.90 & 15.08 \\ 163.90 & 200.90 & 211.90 & \\ 2.88 & 3.50 & 3.68 & 15.71 \\ 7.91 & 9.62 & 10.13 & 0.28 \\ & & & 0.76 \\ 113.80 & 139.50 & 147.20 & 10.91 \\ 2.00 & 2.43 & 2.56 & 0.20 \\ 5.49 & 6.68 & 7.04 & 0.73 \\ 0.47 & 0.47 & 0.39 & 0.03 \\ 3.32 & & & \\ & 3.66 & 3.77 & 0.457\end{array}$

* For details of composition, see Table I.

Total indispensable amino acid concentrations were higher than the control levels when casein was infused. The concentrations of branched-chain amino acids were substantially higher during the casein infusion. Neither of these changes, however, were statistically significant $(P<0.05)$.

\section{Glucose kinetic measurements}

Results for glucose kinetic measurements are given in Table 5. Treatment effects were not significant $(P<0.05)$ but there was a trend which indicated that glucose pool size and the rate of irreversible loss of glucose were increased by both casein and glucose infusions. Plasma glucose concentrations were also higher during these infusions.

\section{DISCUSSION}

Milk and total protein production were increased by 17 and $20 \%$ respectively when casein was infused, whereas the only effect of glucose infusion was to reduce the amount of milk fat from $46 \cdot \mathrm{I}$ to $38.3 \mathrm{~g} / \mathrm{l}$. The responses to casein infusion were similar to the values of 22 and $23 \%$ for milk and total protein production respectively recorded previously with goats (Ranawana \& Kellaway, 1977), and greater than most responses recorded with cows (Clark, 1975). Clark et al. (1973) and Tyrell, Bolt, Moe \& Swan (1972) found that milk production was increased by infusions of casein, but not glucose. However, infusions of glucose either intravenously (Linzell, 1967) or intra-arterially (Mepham \& Linzell, 1974) were found to increase milk production. The apparent increases which we found in glucose pool sizes and irreversible entry rates when either casein or glucose were infused are consistent with the glucogenic 
nature of casein. Exogenous glucose reduces endogenous glucose production in ruminants when infused at rates similar to or in excess of the irreversible loss rates before infusion (Annison \& White, 1961; Bartley \& Black, 1966). In our experiment, where exogenous glucose was infused at one-third the rate of irreversible loss before infusion, there was apparently no effect on endogenous glucose production.

Infusion of glucose does not necessarily mimic gluconeogenesis from casein in that sites at which the extra glucose becomes available may differ and this may lead to different hormonal responses. However, both casein and glucose infusions resulted in higher arterial concentrations of glucose so that availability of glucose to the udder was enhanced with both treatments. In view of the fact that milk production was increased with casein infusion but not with glucose infusion, it is reasonable to conclude that the response to casein was not directly effected by gluconeogenesis.

The reduction in the fat content of milk is consistent with other reports (Fisher \& Elliott, 1966; Clark et al. 1973; Vik-Mo et al. 1974) and is apparently due to a decrease in blood-borne precursors of milk fat when the uptake of glucose, propionate or other glucogenic substances is increased (Annison, Bickerstaffe \& Linzell, 1974). The smaller decrease in the fat content of milk with casein infusion was not significant, but conforms with the trend in glucose kinetics indicating that casein did not increase glucose pool size or irreversible loss to the same extent as did glucose. The irreversible glucose losses found in the present study are somewhat less than those reported by Annison \& Linzell (1964) in the lactating goat, which may be attributed to differences in levels of milk production (Bergman \& Hogue, 1967 ).

The $\mathrm{N}$ balance results indicated that, similar to the findings of our previous experiment (Ranawana \& Kellaway, 1977), the goats were in positive $\mathrm{N}$ balance when given the basal ration. In contrast to the results of the previous experiment, however, the utilization of infused casein was poorer, with $73 \%$ of the infused $\mathrm{N}$ appearing in the urine. This may be attributed to the lower level of milk production $(169 \circ \mathrm{g} / \mathrm{d})$ from goats in mid-lactation compared with the higher level of milk production found in the previous experiment $(2662 \mathrm{~g} / \mathrm{d})$ from goats in early lactation.

The increase in plasma concentrations of indispensable amino acids, particularly the branched-chain amino acids, with casein infusion, is consistent with earlier reports (Hogan, Weston \& Lindsay, 1968; Papas, Hatfield \& Owens, 1974; Ranawana \& Kellaway, 1977). The finding that glucose infusion increased circulating levels of dispensable amino acids is of considerable interest in view of the finding of Halfpenny, Rook \& Smith (1969) that increasing the level of energy in the diet of dairy cows led to increases in plasma levels of total dispensable amino acids.

The hypothesis tested in this experiment was that milk production was being limited by the availability of glucose to the mammary gland. The results indicated that glucose was not limiting and that increases in milk production following casein infusion were not attributable to gluconeogenesis from casein. Intravenous infusion of certain amino acids causes an increase in levels of growth hormone in blood plasma of humans (Knopf, Conn, Fajans, Floyd, Guntsche \& Rull, 1965) and cows (Hertelendy, Takahashi, Machlin \& Kipnis, 1970) and administration of growth hormone to lactating cows increases milk yield (Cowie, 1966; Machlin, 1973). In view of the 
substantial increases in milk production found in the present study, it will be of considerable interest to examine the possible role of growth hormone in the response to infused casein.

We thank Professor E. F. Annison for guidance in making glucose kinetic measurements, and Miss K. Maurer and Mr R. Moore for technical assistance. This study was supported by the Australian Dairying Research Committee.

\section{REFERENCES}

Annison, E. F., Bickerstaffe, R. \& Linzell, J. L. (r974). F. agric. Sci., Camb. 82, 87.

Annison, E. F, \& Linzell, J. L. (I 964). F. Physiol,, Lond. 175, 372.

Annison, E. F. \& White, R. R. (196r). Biochem. F. 80, I62.

Bartley, J. C. \& Black, A. L. (1966). F. Nutr. 89, 3 г7.

Bergman, E. N. \& Hogue, D. E. (r967). Am. F. Physiol. 213, 1378.

Clark, J. H. (1975). F. Dairy Sci. 58, II78.

Clark, J. H., Spires, H. R. \& Derrig, R. G. (1973). F. Anim. Sci. 37, 340.

Cowie, A. T. (1966). In The Pituitary Gland, vol. I [G. W. Harris and B. T. Donovan, editors]. London: Butterworths.

Fisher, L. J. \& Elliott, J. M. (Ig66). F. Dairy Sci. 49, 826.

Halfpenny, A. F., Rook, J. A. F. \& Smith, G. H. (1969). Br. F. Nutr. 23, 547.

Hardwick, D. C., Linzell, J. L. \& Price, S. M. (r 96r). Biochem. F. 80, 37.

Hertelendy, F., Takahashi, K., Machlin, L. \& Kipnis, D. M. (1970). Gen. Comp. Endocrinol. 14, 72.

Hogan, J. P., Weston, R. H. \& Lindsay, J. R. (1968). Aust. F. biol. Sci. 21, 1263.

Huggett, A. St G. \& Nixon, D. A. (1957). Lancet ii, 368.

Katz, J., Dunn, A., Chenoweth, M. \& Golden, S. (1974). Biochem. F. 142, I7I.

Knopf, R. F., Conn, J. W., Fajans, S. S., Floyd, J. C., Guntsche, E. M. \& Rull, J. A. (1965). F. clin. endocr. Metab. 25, I 140.

Linzell, J. L. (1967). F. Physiol., Land. r9o, 347.

Machlin, L. J. (1973). F. Dairy Sci. 56, 575.

Mepham, T. B. \& Linzell, J. L. (1974). F. Dairy Res. 4x, I I.

Papas, A., Hatfield, E. E. \& Owens, F. N. (1974). F. Nutr. ro4, 1543.

Perry, T. L. \& Hansen, S. (1959). Clinica chim. Acta 25, 53.

Ranawana, S. S. E. \& Kellaway, R. C. (1976). Aust. Soc. anim. Prod. r1, 489.

Ranawana, S. S. E. \& Kellaway, R. C. (1977). Br. F. Nutr. (In the Press.)

Schmidt, S. P., Smith, J. A. \& Young, J. W. (1975). F. Dairy Sci. 58, 952.

Tyrell, H. F., Bolt, D. V., Moe, P. W. \& Swan, H. (1972). F. Anim. Sci. 35, 277.

Vik-Mo, L., Emery, R. S. \& Huber, J. T. (1974). F. Dairy Sci. 57, 869.

Wolff, J. E. \& Bergman, E. N. (1972). Am. F. Physiol. 223, 455. 